\title{
Adjustment of Logic Operational Chemical Injection Pump in pH Control of Water Steam Cycle to Improve Steam Turbine 5.8 Reliability of Power Plant PT. PJB UP Muara Tawar
}

\author{
Erlangga $^{1}$, Ali Sandra ${ }^{1}$, Faris Azharuddin ${ }^{1}$, Riski Aditya ${ }^{1}$ \\ Kevin Sanjoyo Gunawan ${ }^{2}$, Totok R. Biyanto ${ }^{2 *}$ \\ ${ }^{I}$ PT. PJB UP Muara Tawar, Muara Tawar, Indonesia \\ ${ }^{2}$ Engineering Physics Department, Institut Teknologi Sepuluh Nopember (ITS), Surabaya, Indonesia.
}

\begin{abstract}
Water quality in power plant is the main factor of equipment reliability. Standard water quality can assure performance of equipment and minimize equipment defact especially from corrosion. In Block 5 UP Muara Tawar, water is used to producing steam from HRSG. Actually $\mathrm{pH}$ for HP drum is $30 \%$ above the upper limit. To overcome this problem, it is needed to do some adjustment with the method as follows: data collection from process information system, brainstorming with operation, engineering and instrumentation to improve quality of water for short and long term period of operation, perform temporary corrective maintenance by Operate CBD in higher opening Operate phospate chemical injection manually based on $\mathrm{pH}$ set point or regulate based on time, literature review about logic system of phospate chemical injection in drum and make a research plan to find source of problem. From adjustment of operational logic injection pump the $\mathrm{pH}$ and conductivity value is under control in both higher and lower limit. It is shown that pH value are laid in 9.0-9.4. Moreover, the actual conductivity value are about $7.23 \mu \mathrm{s} / \mathrm{cm}$ and $21.34 \mu \mathrm{s} / \mathrm{cm}$, respectively. It is match with $A B B$ conductivity limit i.e. maximum $40 \mu \mathrm{s} / \mathrm{cm}$. Morover, water consumption decrease from $6413 \mathrm{~m} 3 /$ days to $45.1 \mathrm{~m} 3 /$ days
\end{abstract}

Keywords: chemical, $C B D, p H$, reliabiity, water

\section{Introduction}

Water quality in power plant is the main factor of equipment reliability. Standard water quality can assure performance of equipment and minimize equipment defact especially from corrosion [1]. Block 5 UP Muara Tawar is combine cycle power plant that built in 2011.

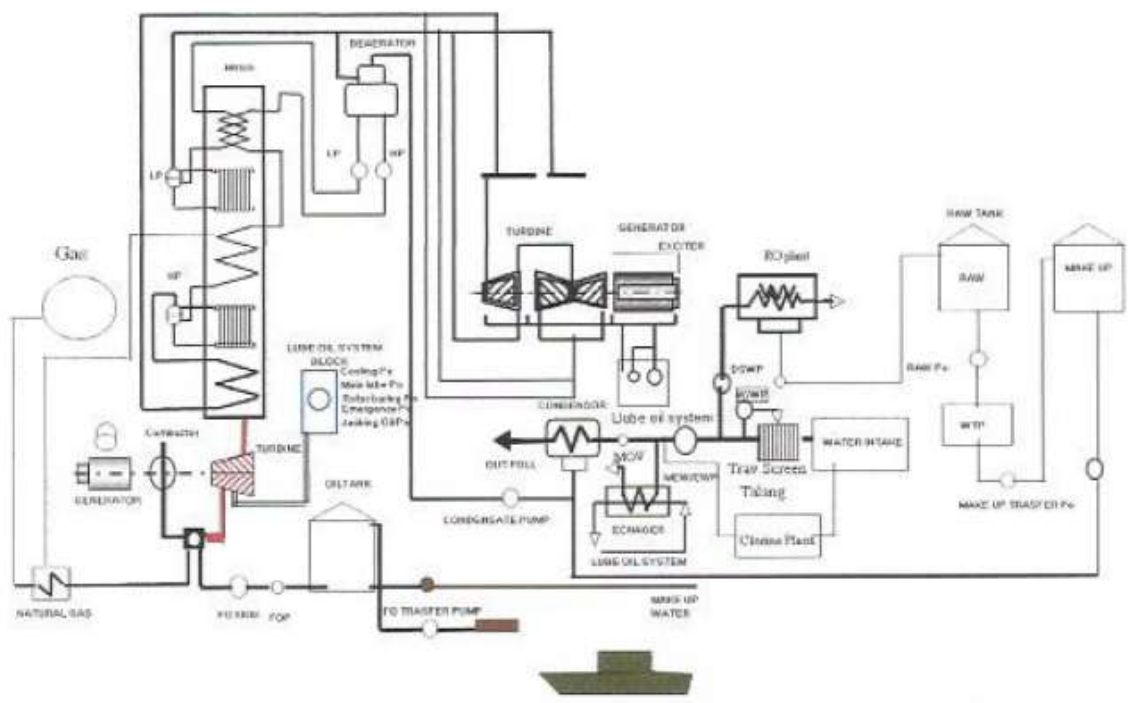

Figure 1. Combined Cycle Power Plant

In Fig. 1, steam turbine require superheated steam to produce electricity. The steam is produced in HRSG [2] and it is condensed by condenser as water steam cycle [3]. In order to minimize equipment failure, the water quality should be monitored using online monitoring displayed in HMI and offline monitoring by laboratory work. Water quality control is performed by chemical injection control. 
Chemical injection control is connected to integrated logic to allow proper operating condition. Steam turbine 5.8 is a new unit that operate from 2011 in UP Muara Tawar. Sometimes erected plant required some modification in operational stage to match with process requirement. $\mathrm{pH}$ control function is maintaining acidity of water 9.0 - 9.4. There are two possibilities, lower $\mathrm{pH}$ value tend to corrosion problem, in higher value the scaling will present. In actual most of $\mathrm{pH}$ value is reach above upper limit. It condition trigger some risk as follow:

- Scaling/deposit, that cause reduce overall heat transfer coefficient in heat transfer equipment (HRSG) and cause mass unbalance in turbine blade that lead to plant trip due to high vibration [4].

- Deposit or fouling cause metal corrosion in equipment and piping that reduce plant life time [5].

- Caustic embritliement in HRSG will affect to deposit fouling that reduce plant reliability and availability.

- Increase water consumption due to rapid valve opening in continous blowdown system (CBD) to maintain $\mathrm{pH}$ in normal condition.

\section{Theory}

Steam turbine require water steam cycle as energy agent. A steam cycle power plant is operated using the Rankine cycle. Water enters a boiler where it is heated to create steam. The steam is then sent through a steam turbine that rotates the shaft of a generator to create electricity. The steam exits the turbine into a condenser, which converts the steam back into saturated water. The saturated water is then pumped back into the boiler to repeat the process. Water quality is very important due to affect to turbine lifetime, reduce overall heat transfer coefficient and turbine efficiency. The water quality influence to:

1. Corrosion rate [6]

2. Scaling in piping system

3. Scaling in blade turbine

Chemical parameter that should be controlled in water steam cycle as follows:

1. $\mathrm{pH}$, this parameter indicate the acidity of the fluid that affect corrosion and embrittlement to the system.

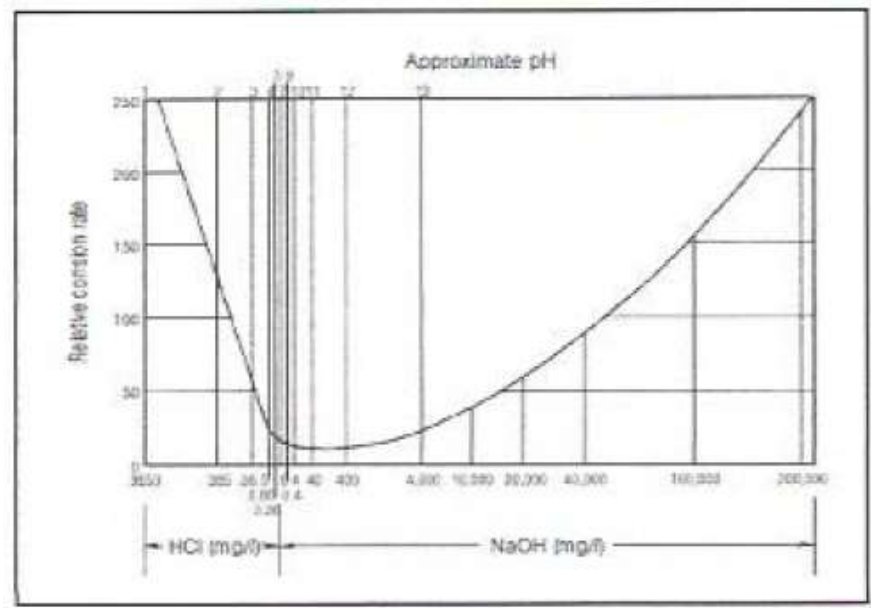

figure 2. pH Diagram and Corosion Rate

Fig. 2 shows the low corrosion regime at $\mathrm{pH} 9-12$. Hence, the $\mathrm{pH}$ control set point should be in this range by manipulate the flow rate of $\mathrm{NH}_{4} \mathrm{OH}$ and $\mathrm{Na}_{3} \mathrm{PO}_{4}$ that flow into the water steam cycle.

2. Conductivity, this parameter indicated ammount of mineral dissolved in the water. This mineral can build scale in piping system and turbine blade. Scaling in pipe will reduce overall heat transfer while scaling in blade turbine will cause unbalance and high vibration. If this happen it can make plant failure so the conductivity need to be maintain.

3. Dissolve oxygen, this parameter has close correlation with $\mathrm{Fe}_{3} \mathrm{O}_{4}$ that inhibit corrosion on the metal surface, however more oxygen contain lead to higher corrosion rate [7].

4. Chloride level, chloride is agresive ion that creates corrosion cracking in the turbine and in the boilers.

5. Silica content, cause mass unbalance in turbine blade that lead to plant trip due to high vibration

6. Residual chemical content $\left(\mathrm{NH}_{3}, \mathrm{Na}_{3} \mathrm{PO}_{4}, \mathrm{~N}_{2} \mathrm{H}_{4}\right)$ should be continous monitored in order to maintain $\mathrm{pH}$ in water steam cycle. 


\section{Method}

The method of this research can be described as follows:

1. Data collection from process information system.

2. Brainstorming with operation, engineering and instrumentation to improve quality of water for short and long term period of operation.

3. Perform temporary corrective maintenance by operate CBD in higher opening and operate phospate chemical injection manually based on $\mathrm{pH}$ set point or regulate based on time.

4. Literature review about logic system of phospate chemical injection in drum.

5. Make a research plan to find source of problem.

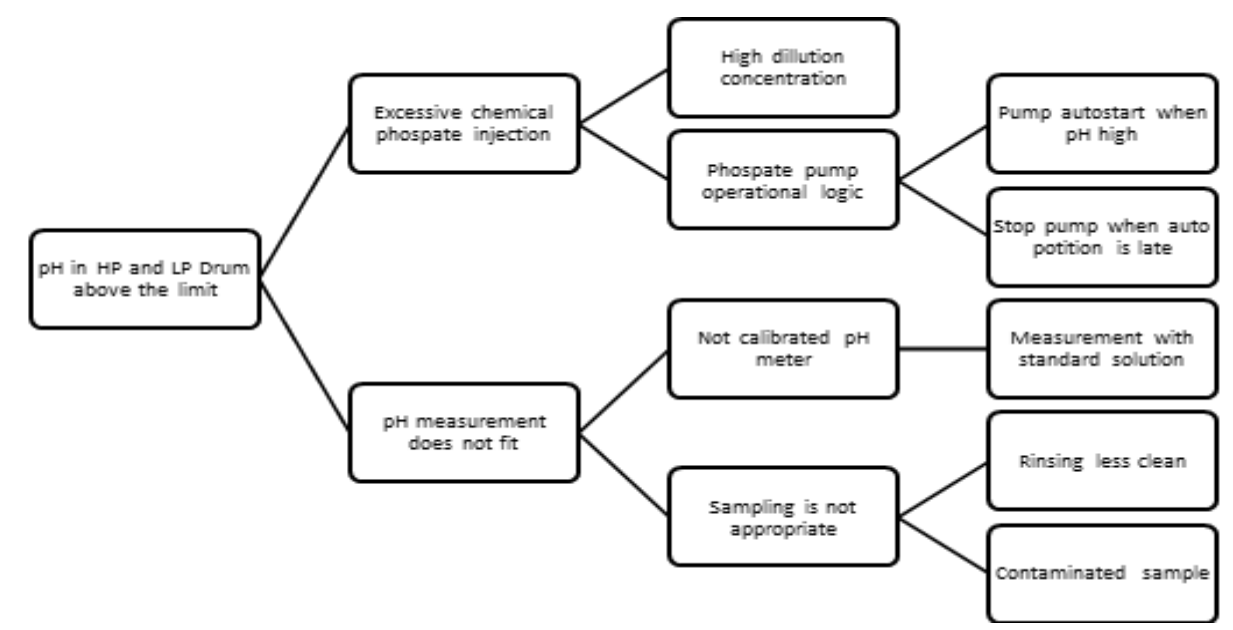

Figure 2. Research Diagram

Problem in Fig. 2 can be tested as follow

Table 1. Suspected Problem and Result

\begin{tabular}{|l|l|l|l|l|}
\hline No & Suspected Problem & Test & Result & Conclusion \\
\hline 1 & $\begin{array}{l}\text { Measurement with high } \\
\text { standard solution }\end{array}$ & $\begin{array}{l}\text { Validation with standard solution } \mathrm{pH} \\
4,7,9\end{array}$ & Small error & Not the cause of problem \\
\hline 2 & $\begin{array}{l}\text { Rinsing of sample bottle is } \\
\text { not clean }\end{array}$ & Rinsing with correct procedure & $\mathrm{pH}$ not change & Not the cause of problem \\
\hline 3 & Contaminated sample & Labelling sample bottle & & Not the cause of problem \\
\hline 4 & $\begin{array}{l}\text { Auto start of pump is not } \\
\text { correct }\end{array}$ & Operational monitoring of pump start & Pump operating in high $\mathrm{pH} 9.7$ & Can be the problem \\
\hline 5 & Pump stop too late & Operational monitoring of pump stop & Pump still operating in high Ph & Can be the problem \\
\hline
\end{tabular}

From Table 1 can be concluded that the potential problem is phospate pump operational. This potential problem can cause an increase of $\mathrm{pH}$ level in drum due to excess phospate injection.

\subsection{Data pH Drum}

\section{Discussion} 2012).

pH level in HRSG 5.8 drum in UP Muara Tawar is above the upper limit (shown by data from May

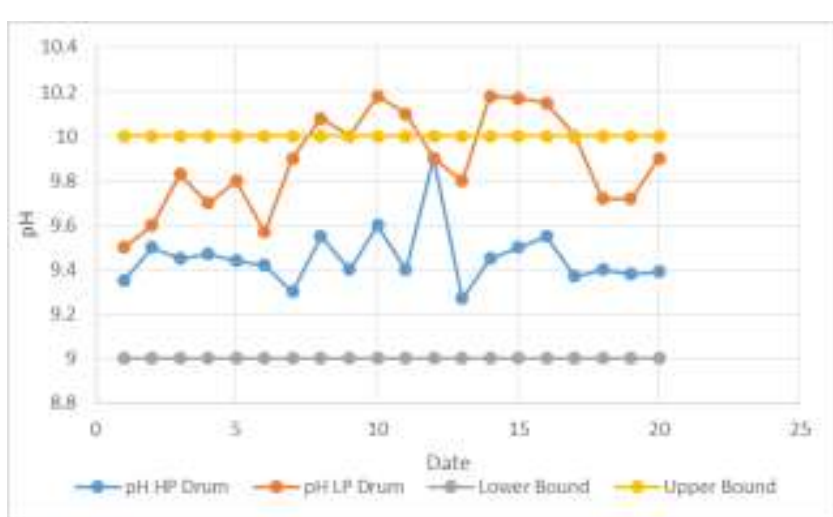

Figure 3. Trend pH LP and HP Drum on May 2012 
Fig. 3 show that $\mathrm{pH}$ for HP drum $30 \%$ above the upper limit. Temporary action to overcome this problem is increase continous blowdown valve opening or open intermitten blowdown to reduce $\mathrm{pH}$ level in drum. However, increase in opening of CBD and IBD will proportional with fresh water consumption (64.13 $\mathrm{m}^{3} /$ day).

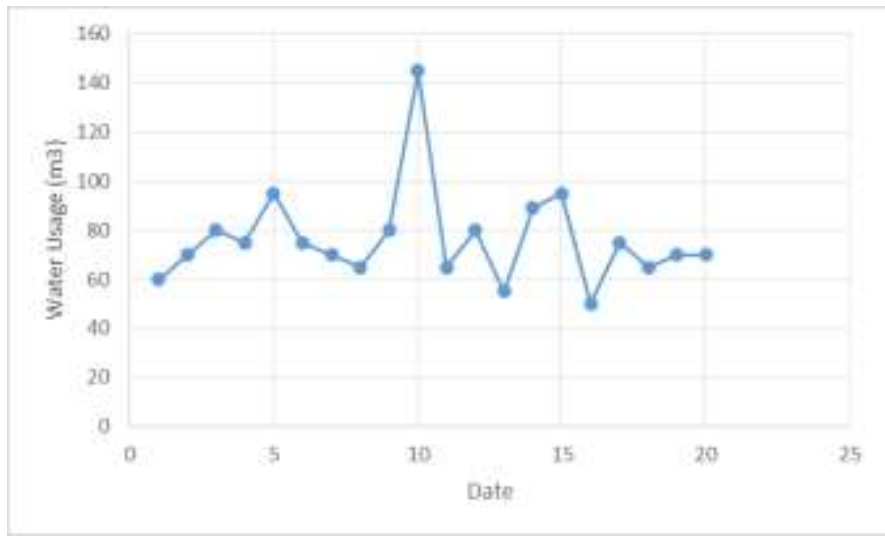

Figure 4. Fresh Water Used in May 2014

\subsection{Phospate Injection}

From temporary corrective maintenance that has been performed by phospate injection manually (injection pump start in $\mathrm{pH} 9.1$ and stop in $\mathrm{pH}$ 9.3) was obtained the performance of $\mathrm{pH}$ monitoring as shown in Fig. 5.

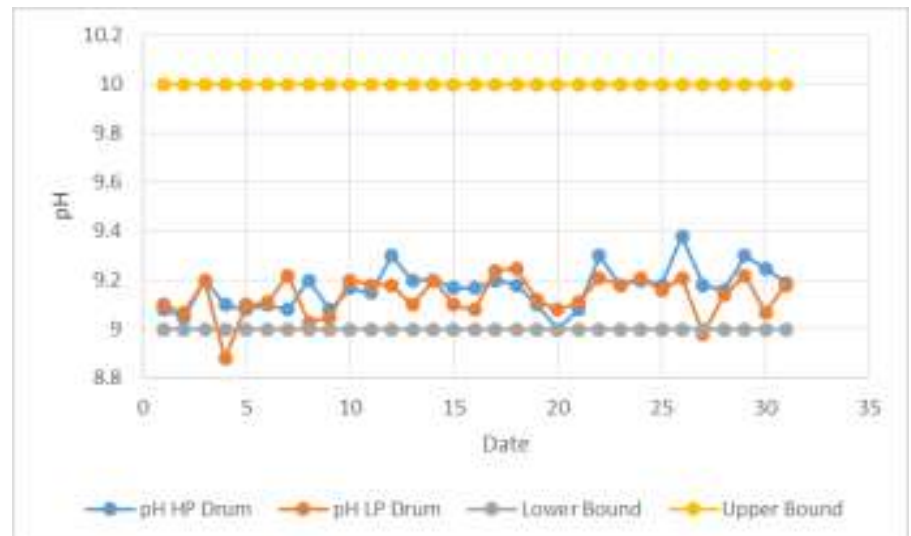

Figure 5. pH in HP And LP Drum on January 2014

Fig. 5 show the $\mathrm{pH}$ value has been maintained at the range of 9.0-9.4, It indicate the problem has been solved by operate injection pump manually. There are out of control $\mathrm{pH}$ below lower limit. It happen due to sampling time perform every 4 hours. To overcome this non conformance, application of control automatic in injection pump is necessary, by considering the time interval of pump working.

\subsection{Improvement in Phospate Injection Pump Logic Diagram}

In order the control phospate injection pump automatically, parameter in logic ALSPA (Alstom Product Automation) should be improved as follow:

1. HP Drum

Pump status start if:

- pH (51 QUL 05 CQ 031) = 9.25

- Conductivity (51 QUL 05 CQ 011) = $4.5 \mu \mathrm{s} / \mathrm{cm}$

Pump status stop if:

- $\mathrm{pH}(51$ QULO5CQ 031) $=9.45$

- Conductivity (51 QUL 05 CQ 011) = $35 \mu \mathrm{s} / \mathrm{cm}$

Interlock

If CBD open, pump status on.

\section{LP Drum}


Pump status start if:

- $\mathrm{pH}(51 \mathrm{QULO5CQO31})=9.25$

- Conductivity (51 QUL 05 CQ 011) = $4.5 \mu \mathrm{s} / \mathrm{cm}$

Pump status stop if:

- pH (51 QUL 01 CQ 031) = 9.45

- Conductivity (51 QUL 01 CQ 011) = $35 \mu \mathrm{s} / \mathrm{cm}$

Interlock

If CBD open, pump status on.

Adjustment for logic parameter was performed in 9 October 2014 as follow:

- Changing status of pump on from 9.25 to 9.1

- Changing status of pump on by conductivity value from $4.5 \mu \mathrm{s} / \mathrm{cm}$ to $0 \mu \mathrm{s} / \mathrm{cm}$

- Changing status of pump off from 9.45 to 9.3

- Remove interlock beetween CBD and pump

Parameter adjustment in logic diagram of injection pump PLC are based on the experimental data obtained from plant operation manually. The performance of the system after adjustment as follows:

1. Actual $\mathrm{pH}$ value from the plant HP and LP drum can be shown in Figure 6.

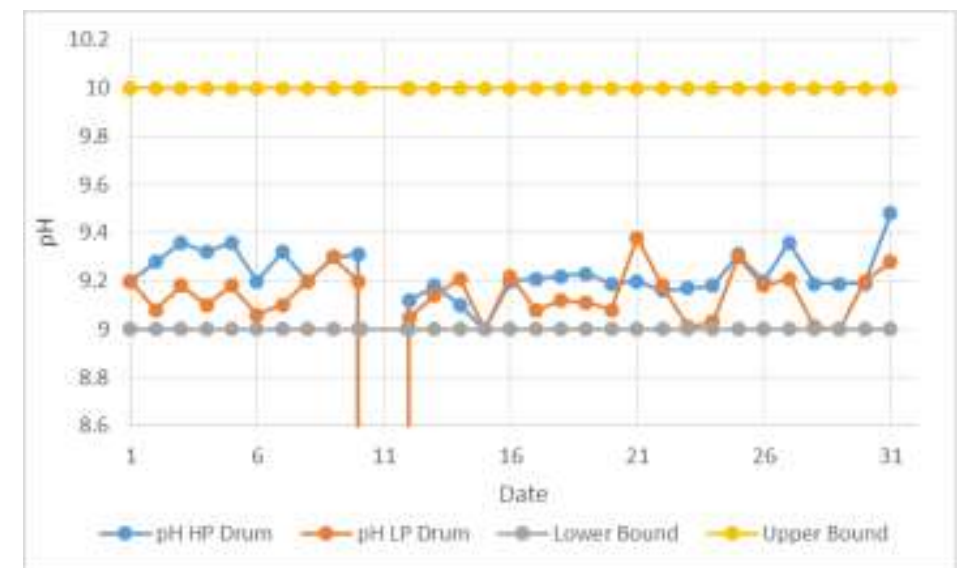

Figure 6. pH in HP and LP Drum on October 2014

Fig. 6 shows the variation of $\mathrm{pH}$ value are laid in 9.0-9.4, it mean the value in beetween lower and upper limit. The lower value of $\mathrm{pH}$ on 10 th -12 th of October due to abnormal operating conditions. In another word this range of $\mathrm{pH}$ is laid in non corossive regime based on Kurita Handbook of water treatment.

2. Actual conductivity value from the plant HP and LP drum can be shown in Figure 7.

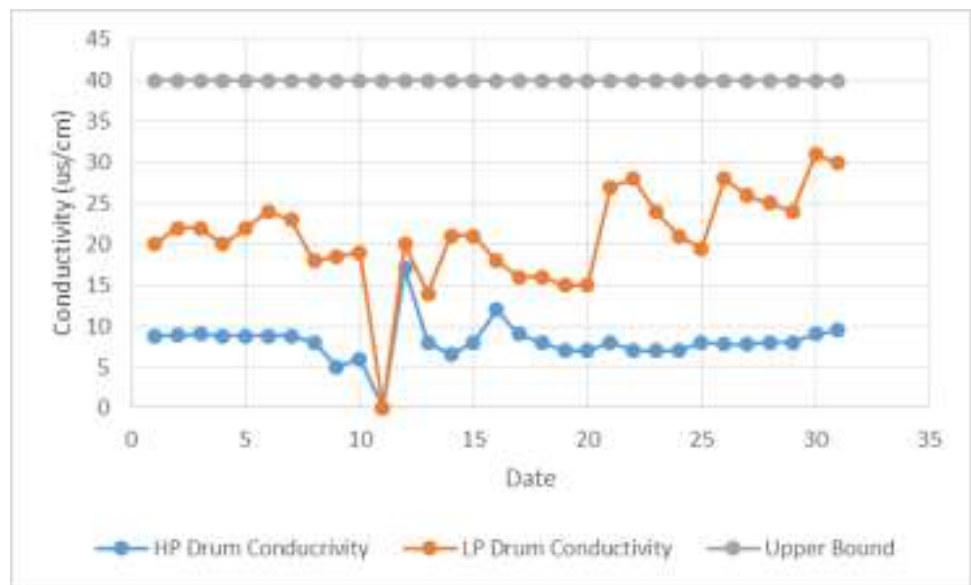

Figure 7. Conductivity in HP and LP Drum on October 2014 
Fig. 7 shows the actual conductivity in HP and LP drum are about $7.23 \mu \mathrm{s} / \mathrm{cm}$ and $21.34 \mu \mathrm{s} / \mathrm{cm}$, respectively. It is match with $\mathrm{ABB}$ conductivity limit i.e. maximum $40 \mu \mathrm{s} / \mathrm{cm}$.

3. Fresh water consumption

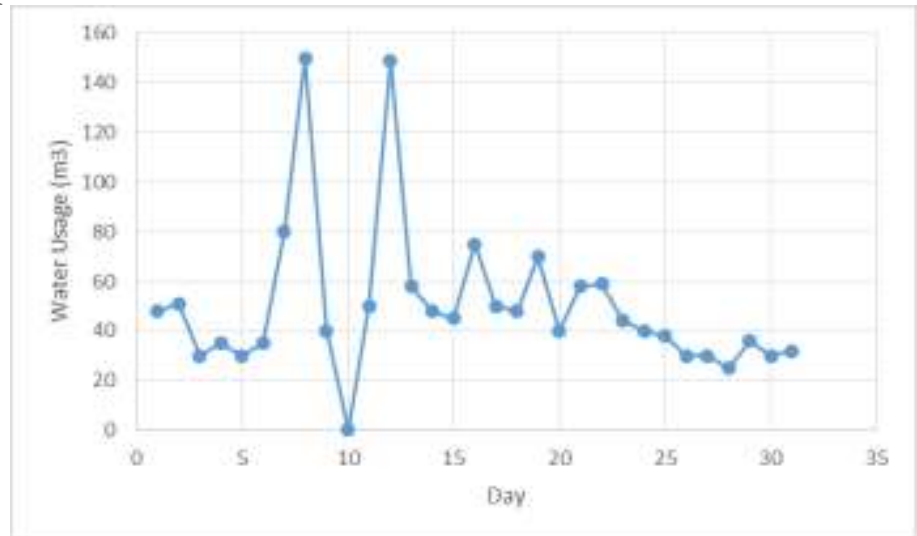

Figure 8. Fresh Water Used on October 2014

Since 9 October - 31 October, water cosnumption slightly stable at the value $45.1 \mathrm{~m}^{3} /$ days. It is mean adjustment in logic diagram of operational injection pump provide saving of water that previously the fresh water consumption is about $6413 \mathrm{~m}^{3} /$ days.

\section{Conclusion}

Adjustment of logic operational injection pump have been performed and the $\mathrm{pH}$ and conductivity value is under control in both higher and lower limit. It is shown that $\mathrm{pH}$ value are laid in 9.0-9.4. Moreover, the actual conductivity value are about $7.23 \mu \mathrm{s} / \mathrm{cm}$ and $21.34 \mu \mathrm{s} / \mathrm{cm}$, respectively. It is match with ABB conductivity limit i.e. maximum $40 \mu \mathrm{s} / \mathrm{cm}$. Morover, water consumption decrease from $6413 \mathrm{~m}^{3} /$ days to 45.1 $\mathrm{m}^{3} /$ days.

\section{Acknowledgement}

The authors gratefully thank to PT. PJB UP Muara Tawar - Indonesia for providing the facilities in conducting this research.

\section{References}

[1]. B. Ali and A. Kumar, "Development of life cycle water footprints for gas-fired power generation technology," Energy Conversion Management, vol. 110, no. 15, pp. 386-396, 2016.

[2]. J. Li, K. Wang and L. Cheng, "Experiment and optimization of a new kind once-through heat recovery steam generator (HRSG) based on analysis of exergy and economy," Applied Thermal Engineering, vol. 120, pp. 402-415, 2017.

[3]. G. Olson, Water and Energy: threats and opportunities, London: IWA Publisher, 2012.

[4]. H. Xu, B. Deng, D. Jiang, Y. Ni and N. Zhang, "The finite volume method for evaluating the wall temperature profiles of the superheater and reheater tubes in power plant," Applied Thermal Engineering, vol. 112, pp. 362-370, 2017.

[5]. G. C. Comley, "The significance of corrosion products in water reactor coolant circuits," Energy, vol. 16, pp. 41-72, 1985.

[6]. S. Vidojkovic, A. Onjia, B. Matovic, N. Grahovac, V. Maksimovic and A. Nastasovic, "Extensive feedwater quality control and monitoring concept for preventing chemistry-related failures of boiler tubes in a subcritical thermal power plant," Applied Thermal Engineering, vol. 59, pp. 683-694, 2013.

[7]. G. S. Was, P. Ampornrat, G. Gupta, S. Teysseyre, E. A. West, T. R. Allen and K. Sridharan, "Corrosion and stress corrosion cracking in supercritical water,", Material, vol. 371, pp. 176-201, 2007. 